3 International Agency for Research on Cancer. Monograph on the evaluation of carcinogenic risk of chemicals in humans. Vol 38. Tobacco smoking. Lyon: IARC, 1986.

4 Phillips DH, Hewer A, Martin CN, Garner RC, King MM. Correlation of DNA adduct levels in human lung with cigarette smoking. Nature 1988;336:790-2.

5 Phillips DH, Schoket B, Hewer A, Bailey E, Kostic S, Vincze I. Influence of cigarette smoking on the levels of DNA adducts in human bronchial epithelium and white blood cells. Int I Cancer 1990;46:569-75.

6 Dunn BP, Vedal S, San RH, Kwan WF, Nelems B, Enarson DA, et al. DNA adducts in bronchial biopsies. Int $\mathcal{F}$ Cancer 1992;48:485-92.

7 Randerath E, Millar R, Mittal D, Avitts TA, Dunsford HA, Randerath K. Covalent DNA damage in tissues of cigarette smokers as determined by 'P-postlabelling assay. $\mathcal{F}$ Natl Cancer Inst 1989;81:341-7.

8 McCann MF, Irwin DE, Walton LA, Hulka BS, Morton Jle, Axelrad CM. Nicotine and cotinine in the cervical mucus of smokers, passive smoker and nonsmokers. Cancer Epidemiology Biomarkers and Prevention 1992;1: $125-9$.

9 Sasson IM, Haley NJ, Hoffmann D, Wynder EL, Hellberg D, Nilsson S Cigarette smoking and neoplasia of the uterine cervix: smoke constituents in cervical mucus. $N$ Engl $\mathcal{H}$ Med 1985;312:315-6.

10 Schoket B, Horkay I, Kósa A, Páldeák L, Hewer A, Grover PL, et al. Formation of DNA adducts in the skin of psoriasis patients, in human skin in organ culture and in mouse skin and lung following topical application of in organ culture and in mouse skin and lung following topic

11 Gupta R. Enhanced sensitivity of "P-postlabelling analysis of aromatic carcinogen: DNA adducts. Cancer Res 1985;45:5656-62.
conta

12 Gupta R, Reddy MV, Randerath K. "P-postlabelling analysis of nonradioactive aromatic carcinogen-DNA adducts. Carcinogenesis 1982;3 1081-92
13 Reddy MV, Randerath K. Nuclease Pl-mediated enhancement of sensitivity of "P-postlabelling test for structurally diverse DNA adducts. Carcinogenesis 1986;7:1543-51.

14 Feyerabend C, Russell MAH. Rapid gas chromatography determination of cotinine in biological fluids. Analyst 1980;105:998-1001.

15 Cuzick J, Routledge MN, Jenkins D, Garner RC. DNA adducts in different tissues of smokers and non-smokers. Int $\mathcal{F}$ Cancer 1990;45:673-8.

16 Hoffmann D, Hecht SS. Advances in tobacco carcinogenesis. In: Cooper CS, Grover PL, eds. Handbook of experimental pharmacology. Vol 94/1. Chemical

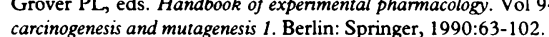

17 Miller EC, Miller JA. Searches for ultimate chemical carcinogens and their reactions with cellular macromolecules. Cancer 1981;47:2327-45.

18 Benowitz NL, Kuyt F, Jacob III P, Jones RT, Osman A-L. Cotinine disposition and effects. Clin Pharmacol Ther 1983;34:604-11.

19 Sillet RW, Wilson MB, Malcolm RE, Ball KP. Deception amongst smokers. BMF 1978;ii:1185-6.

20 Wilcox RG, Hughes J, Roland J. Verification of smoking history in patients after infarction using urinary nicotine and cotinine measurements. $B M$ 1979;ii:1026-8.

21 Phillips DH, Hewer A, Malcolm ADB, Ward P, Coleman DV. Smoking and DNA damage in cervical cells. Lancet 1990;335:417.

22 Action on Smoking and Health (ASH). Teenage girls and smoking. London: ASH, 1986.

23 Office of Population Censuses and Statistics. Cigarette smoking 1972-1990. OPCS Monitor 1991;SS91/3.

24 Royal College of Physicians Working Party. Smoking and the young (5th report). London: Royal College of Physicians, 1992.

25 Sasco AJ. World burden of tobacco-related cancer. Lancet 1991;338:123-4.

(Accepted 29 March 1993)

\title{
Protection of children by their mothers against sunburn
}

\section{Paul Jarrett, Caroline Sharp, Janet McLelland}

\section{Department of \\ Dermatology, Sunderland \\ Royal Infirmary, \\ Sunderland SR2 7JE \\ Paul Jarrett, senior house \\ officer \\ Caroline Sharp, clinical \\ assistant \\ Janet McLelland, consultant \\ dermatologist}

Correspondence to:

Dr McLelland.

BMF 1993;306:1448
There is evidence that episodes of sunburn increase the risk of developing malignant melanoma, ${ }^{12}$ especially sunburn in childhood. ${ }^{3-5}$ In Australia there have been extensive public education campaigns alerting people to the dangers of excessive sunlight exposure, including the slip (on a shirt), slop (on sun cream), and slap (on a hat) campaign. In Britain there has been less publicity, but the incidence of malignant melanoma is increasing.

This study looks at the practices of mothers in Sunderland (a town not noted for its sunny climate) in protecting their children from the sun and the incidence of sunburn among these children.

\section{Methods and results}

During September and October 1991, 200 mothers attending the paediatric department of Sunderland District General Hospital were interviewed. They were questioned about their youngest children, up to a maximum of three per family, and only those children aged under 20 were included. The mothers were asked how many times their children had been sunburnt (defined as more than $1 \%$ of the total body area going red several hours after exposure to the sun) in the previous year.

Information on 416 children was obtained, of whom 159 had been sunburnt at least once, 150 having been burnt in Britain. Of the 416 children, 75 had been burnt once in the previous year; 29 had been burnt

Children of different ages, exposed to the sun without a shirt, with a hat worn, or with sun cream applied

\begin{tabular}{lcccccc}
\hline & \multicolumn{7}{c}{ Children's age (years) } \\
\cline { 2 - 7 } & $\begin{array}{c}<1 \\
(n=28)\end{array}$ & $\begin{array}{c}1-2 \\
(n=71)\end{array}$ & $\begin{array}{c}3-4 \\
(n=63)\end{array}$ & $\begin{array}{c}5-9 \\
(n=129)\end{array}$ & $\begin{array}{c}10-15 \\
n=103)\end{array}$ & $\begin{array}{c}16-20 \\
(n=22)\end{array}$ \\
\hline $\begin{array}{l}\text { No (\%) exposed to sun without shirt at } \\
\quad \text { least once }\end{array}$ & $4(14)$ & $37(52)$ & $52(83)$ & $106(82)$ & $81(79)$ & $13(59)$ \\
$\begin{array}{l}\text { No (\%) with sun cream applied at least } \\
\text { once }\end{array}$ & $8(29)$ & $42(59)$ & $41(65)$ & $68(53)$ & $60(58)$ & $8(36)$ \\
No (\%) worn hat at least once in sun & $24(86)$ & $62(87)$ & $42(67)$ & $62(48)$ & $44(43)$ & $3(14)$ \\
\hline
\end{tabular}

twice, 17 had been burnt three times, eight had been burnt four times, and 30 had been burnt five or more times. Of the 163 sunburn incidents in the 1-9 year age group, 18 occurred in a paddling pool, 57 occurred while playing at home but not in a paddling pool, and 49 occurred at the seaside (14 on the beach at Sunderland). Only seven children were burnt while sunbathing, and all were over 10 years old.

Altogether $293(70 \%)$ of the children in the survey had been exposed to the sun without a shirt, $227(54 \%)$ had had sun cream applied at least once in the previous year and $237(57 \%)$ had worn a hat in the sun at least once. The table shows the analysis of these factors by age; infants aged $<1$ year were most protected against the sun. Boys were more likely than girls to remove their shirts in the sun (boys:girls $=1 \cdot 7: 1$ ), but there was little difference between the sexes in hat wearing (boys:girls $=1 \cdot 1: 1$ ) and the application of sun cream (boys:girls $=1 \cdot 2: 1$ ). There was no relation between skin type and the use of a shirt, sun cream, or a hat.

\section{Comment}

We found a high incidence of sunburn among the children in the study with $38 \%$ of them having been sunburnt in the previous year, nearly always in Britain. Children under 1 year old tended to be well protected, but protection against the sun declined with age. Skin type did not affect a child's likelihood of wearing a shirt, sun cream, or a hat, suggesting that the increased risk of sunburn in a fair skinned child was not perceived by its mother. There is a need for more public education about the dangers of sunlight, in particular to children, in this country.

We thank the Paediatric Department, Sunderland District General Hospital, for permission to study patients.

1 Mackie RM, Aichison T. Severe sunburn and subsequent risk of primary cutaneous malignant melanoma in Scotland. Br f Cancer 1982;46:955-60. Green A, Sinskind V, Bain C, Alexander J. Sunburn and malignant melanoma. Br f Cancer 1985;51:393-7.

3 Holman CD, Armstrong BK. Cutaneous malignant melanoma and indicators of total accumulated exposure to the sun: an analysis separating histogenetic total accumulated exposure to the sun:
types. $I$ Natl Cancer Inst 1984;73:75-82.

4 Osterlind A, Tucker MA, Stone BJ, Jensen OM. The Danish case control study of cutaneous malignant melanoma. II: Importance of UV-light exposure. of cutaneous malignant mel
Int 9 Cancer 1988;42:319-24.

Int f Cancer 1988;42:319-24.
5 Weinstock MA, Colditz GA, Willett WC, Stampfer MJ, Bronstein BR, Mihm $\mathrm{MC}$, et al. Non-familial cutaneous melanoma incidence in women associated with sun exposure before 20 years of age. Pediatrics 1989;84:199-204. 